\title{
Qualitative and Quantitative Analysis of Aerosols in Sonepat-A National Capital Region of India
}

\author{
Sudesh Chaudhary ${ }^{1 *}$, Naresh Kumar ${ }^{2}$ \\ ${ }^{1}$ Centre of Excellence for Energy \& Environmental Studies, Deenbandhu Chhotu Ram University of Science \& Technology, \\ Sonepat, India \\ ${ }^{2}$ Department of Geography, Govt. College, Gohana, India \\ Email: *sudesh.energy@dcrustm.org
}

How to cite this paper: Chaudhary, S. and Kumar, N. (2017) Qualitative and Quantitative Analysis of Aerosols in Sonepat-A National Capital Region-India. Open Journal of Air Pollution, 6, 65-75.

https://doi.org/10.4236/ojap.2017.62006

Received: January 19, 2017

Accepted: June 11, 2017

Published: June 14, 2017

Copyright $\odot 2017$ by authors and Scientific Research Publishing Inc. This work is licensed under the Creative Commons Attribution International License (CC BY 4.0).

http://creativecommons.org/licenses/by/4.0/

\section{Open Access}

\begin{abstract}
Considering the mounting evidences of the effects of air pollution on health, the present study was undertaken to assess the ambient air quality status in Sonepat region. The $\mathrm{PM}_{10}$ aerosol samples were collected from three sampling sites (DCRUST: Deenbandhu Chhotu Ram University of Science and Technology, University campus, Sector 14: residential cum commercial area, and traffic intersection along National Highway number 1) during January to July 2014 and studied for air quality, metal concentrations and their monthly variations. In addition, free fall dust samples were studied for soluble cations. $\mathrm{PM}_{10}$ concentration was found to be ranging from $120.00 \mu \mathrm{g} / \mathrm{m}^{3}$ to $569.59 \mu \mathrm{g} / \mathrm{m}^{3}, 66.56 \mu \mathrm{g} / \mathrm{m}^{3}$ to $312.45 \mu \mathrm{g} / \mathrm{m}^{3}$ and $80.95 \mu \mathrm{g} / \mathrm{m}^{3}$ to 262.47 $\mu \mathrm{g} / \mathrm{m}^{3}$ at NH-1, Sector-14 and DCRUST respectively. The concentrations of $\mathrm{Na}^{+}, \mathrm{NH}_{4}^{+}, \mathrm{K}^{+}, \mathrm{Ca}^{2+}, \mathrm{Mg}^{2+}$ at sector 14 Sonepat were $52.115 \mathrm{ppm}, 6.755 \mathrm{ppm}$, $13.989 \mathrm{ppm}, 105.845 \mathrm{ppm}$ and $72.574 \mathrm{ppm}$, respectively. At DCRUST site, the concentrations of $\mathrm{Na}^{+}, \mathrm{NH}_{4}^{+}, \mathrm{K}^{+}, \mathrm{Ca}^{2+}, \mathrm{Mg}^{2+}$ were $207.583 \mathrm{ppm}, 0.550$ ppm, 50.573 ppm, 90.659 ppm and 85.024 ppm, respectively. The heavy metals concentrations of $\mathrm{Zn}, \mathrm{Cu}$ and $\mathrm{Cr}$ at $\mathrm{NH}-1$ was $36 \mathrm{ppm}, 17.5 \mathrm{ppm}$ and 95.7 ppm, respectively. The concentration of $\mathrm{Zn}, \mathrm{Cu}$ and $\mathrm{Cr}$ at $\mathrm{NH}-1$ was found to be varying from not detected to $19.7 \mathrm{ppm}, 2.1 \mathrm{ppm}$ to $16.54 \mathrm{ppm}$ and $7.24 \mathrm{ppm}$ to $24.1 \mathrm{ppm}$, respectively. Thus, it was recommended that an integrated assessment of air pollution and health risk should be carried out in Sonepat region at regular intervals of time.
\end{abstract}

\section{Keywords}

Air Pollution, $\mathrm{PM}_{10}$, Heavy Metals, Cations 


\section{Introduction}

Air quality is getting deteriorated day by day and is of a great concern not only in mega cities but developing cities. Numerous studies have been conducted on determination of chemical composition of aerosols and pollution source in mega cities. Atmospheric aerosol is termed as tiny liquid or solid particulate matter suspended in air. The atmospheric aerosol plays direct and indirect role in various atmospheric phenomenons [1]. The direct effect includes absorption or scattering of solar irradiance by aerosols while indirect influence modifies the cloud microphysical properties [2]. The interaction of aerosols with soil might bring change in physical as well as chemical nature of top layer of soil as well as reduce the air pollution index (API) of plants [3] [4].

Anthropogenic emissions of air pollutants (like Particulate Matter and heavy metals) that are linked with rapid urbanization and industrialization in developing countries are severely affecting the environment and human health [5]. Particulate matter pollution is a serious environmental issue mainly due to the presence of toxic substances and trace metals in the atmosphere. Water-soluble ions (ws-ions) are major components of the atmospheric aerosols, especially $\mathrm{PM}_{2.5}$. They can compose up to $60 \%-70 \%$ of the total mass of suspended particulate matter [6]. Heavy metals associated with respirable particles have also been shown to increase lung or cardiopulmonary injuries caused by particulate air pollutant exposure [7] [8]. Natural emissions (crustal minerals, forest fires and oceans), traffic and industrial emissions (combustion of fossil fuel and industrial metallurgical processes) are the principal sources of heavy metals in the ambient air [9] [10] [11]. Traffic emissions also represent potential sources of trace heavy metals, including combustion products from fuel and oil, road construction materials, road dust and wear products from tires, brake linings and bearings [12]. The single most important factor responsible for the deterioration of air quality in the cities is the exponential increase in the number of vehicles. Vehicular pollution contributes to $70 \%$ of total pollution in Delhi, $52 \%$ in Mumbai and 30\% in Calcutta [13] [14] [15]. Long-time exposure to toxic trace metals such as arsenic, cadmium, chromium, nickel even at low concentrations can causes cancer [16]. Aerosol particles in the accumulation size regime $(0.1<$ radius $<1.0 \mu \mathrm{m}$ ) contribute dominantly to visibility degradation and radiative interactions, while particles with aerodynamic diameters less than $10 \mu \mathrm{m}\left(\mathrm{PM}_{10}\right)$, and aerodynamic diameters less than $2.5 \mathrm{~mm}\left(\mathrm{PM}_{2.5}\right)$ are of special interest when health problems are concerned [17]. It is also known that the finer aerosols are important from a human health perspective as they can penetrate deeper into the respiratory system. These particles also have longer atmospheric residence times. Not much information on the air quality of Haryana, which has experienced rapid industrial and vehicular growth during last few decades, is available. Despite the increasing evidence of negative impact of air quality on human health [18], not much data on ambient air quality, a prerequisite for health studies, is available for most of the medium size cities or towns in India, although a large population lives in these cities or towns. The present study was 
intended to find out the concentrations of respirable suspended particulate matter load $\left(\mathrm{PM}_{10}\right)$, cations and anions (free fall dust) and heavy metals concentration in the $\mathrm{PM}_{10}$ fraction of dust in ambient air of Sonepat (National Capital Region).

\section{Methodology}

\subsection{Study Area}

Sonepat is located at $28.98^{\circ} \mathrm{N} 77.02^{\circ} \mathrm{E}$ in the National Capital Region about 40 $\mathrm{km}$ from Delhi. The Yamuna river flows along the eastern boundary. The climate of Sonepat is dry with a hot summer and a cold winter. The weather becomes milder during the monsoon period (July to September). The post-monsoon months of October and November constitute a transition period prior to the onset of winter.

The winter starts in December when day and night temperatures fall rapidly. January is the coldest month when the mean daily minimum temperature is $6^{\circ} \mathrm{C}$ to $7^{\circ} \mathrm{C}$. The district experiences high humidity only during the monsoon period. The period of minimum humidity (less than 20\%) is between April and May. Sonepat is becoming a growing industrial town due to its proximity with Delhi. There is a remarkable growth in export of rice, stainless steel products, paper products, electrical goods and auto parts in the district.

The environment of Sonepat has degraded in the past few years due to rapid urbanization, industrialization, and increase in population, vehicles and commercialization of land available within the town. Three sampling sites which have been selected include NH-1 (S1) which is a National Highway connecting North India to New Delhi, DCRUST (S2) and sector 14 (S3) (Figure 1).

\subsection{Sampling}

The samples of $\mathrm{PM}_{10}$ were collected at all three sites NH-1, DCRUST and Sector 14 from January 2014 to July 2014. $\mathrm{PM}_{10}$ samples were collected for $24 \mathrm{~h}$ at three different sites twice a week. $\mathrm{PM}_{10}$ samples were collected using a high volume air sampler (Model: Lata Envirotech India, APM 154) fitted with a fiberglass filter. All the collected samples were packed in polyethylene covers and transported immediately to the laboratory and analysed for $\mathrm{PM}_{10}$ and heavy metals in $\mathrm{PM}_{10}$ using standard laboratory procedures. In the laboratory the filter papers obtained after sampling were weighed again to determine the mass concentration of $\mathrm{PM}_{10}$.

Aerosols samples of free fall dust were collected from the sampling sites using plastic trays filled with a layer of glass marble balls kept at a height of 15 meters above the ground level using the phenomena of gravity settling. The purpose of using the marble balls in tray was to trap the freely falling dust particles in between the marbles. Dried sample was removed from the trays with the help of a scrapper and the tray as well as marble balls were washed with distilled water to remove the sticky particles, the solution was evaporated at $70^{\circ} \mathrm{C}$ in order to get the sample in dried form and was stored in plastic vials for analysis. 

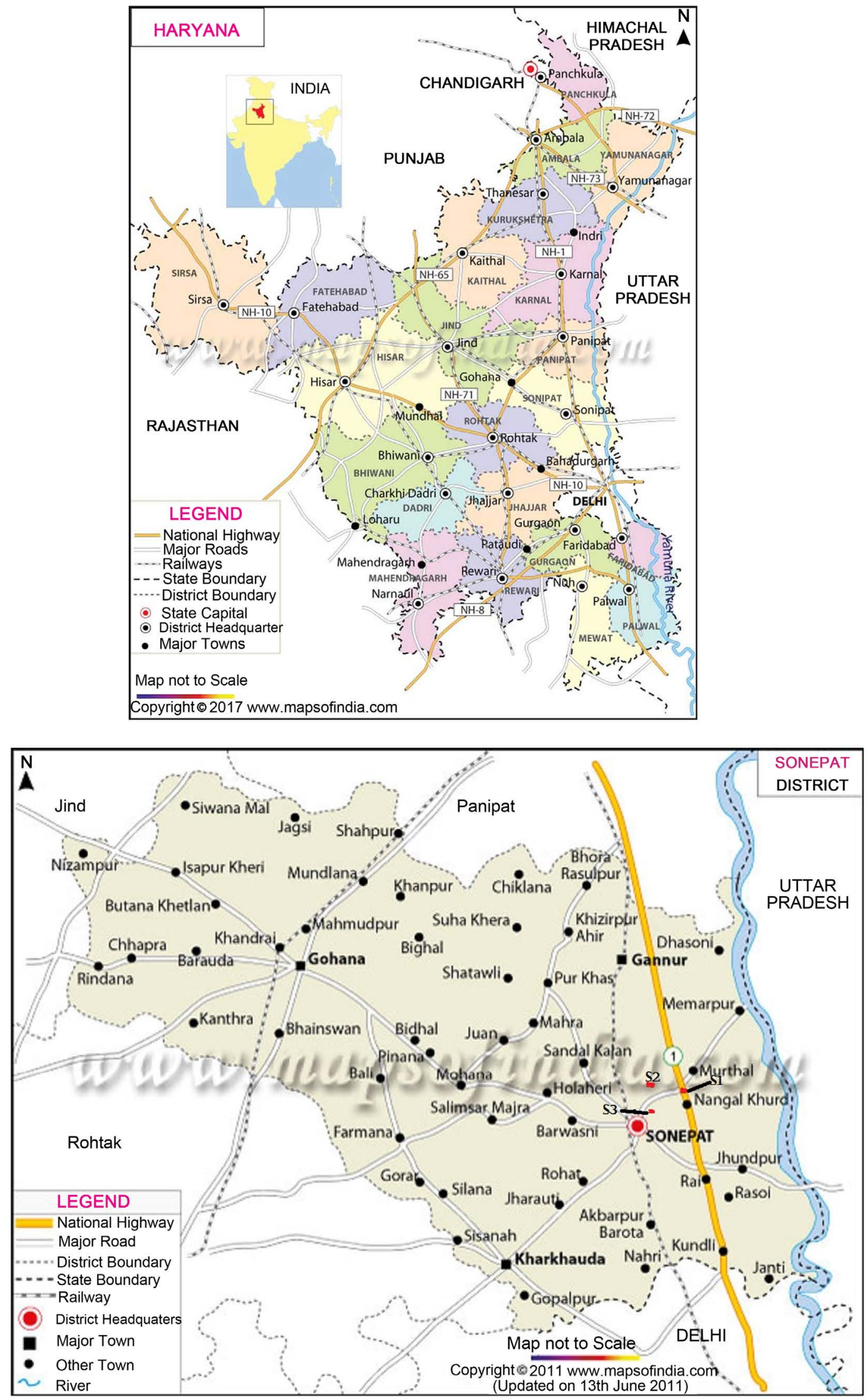

Figure 1. Map showing study area. 


\subsection{Extraction of Heavy Metals}

After sampling, one-fourth of the exposed fiberglass filter, was cut and put in a Teflon crucible, then a mixture of $5 \mathrm{ml}$ of Hydroflouric acid (HF), $10 \mathrm{ml}$ of conc. Nitric acid $\left(\mathrm{HNO}_{3}\right)$ and $1 \mathrm{ml}$ of Perchloric acid $\left(\mathrm{HClO}_{4}\right)$ was taken in the same crucible and was kept on a hot plate at a temperature range of $85^{\circ} \mathrm{C}-90^{\circ} \mathrm{C}$ with the lid on for 4 hours to ensure complete reaction. After 4 hours the lid was removed and the solution was evaporated to dryness. In next step, $10 \mathrm{ml} \mathrm{HF}, 5 \mathrm{ml}$ $\mathrm{HNO}_{3}$ and $1 \mathrm{ml} \mathrm{HClO}_{4}$ was added to above and then heated to dryness. After cooling, in the next stage, $5 \mathrm{ml}$ concentrated Nitric acid was added and heated to dryness. In next step, $20 \mathrm{ml}$ of $1 \mathrm{~N}$ Hydrochloric acid ( $\mathrm{HCl})$ was added to about $100^{\circ} \mathrm{C}$ to bring the digested sample into solution and then transferred to $50 \mathrm{ml}$ flask. This sample was cooled and raised up to $100 \mathrm{ml}$ by adding milli-Q water [19]. The obtained solution was filtered through a Whatman-42 filter paper and stored in a clean and sterile plastic bottle at $4^{\circ} \mathrm{C}$ until further analysis. The digested samples were analyzed for target heavy metals by Atomic absorption spectrometer (Thermo scientific, ice 3000 series).

\subsection{Extraction of Cations}

$2 \mathrm{~g}$ of free fall dust was weighed and transferred to $100 \mathrm{ml}$ conical flask and then $20 \mathrm{ml}$ of milli-Q was added. Solution was thoroughly mixed by shaking conical flask for at least half an hour. Solution was filtered through $0.2 \mu \mathrm{m}$ filter. Now the sample was ready to be inserted in ion exchange chromatography.

\section{Results and Discussions}

\subsection{Seasonal Variation of Particulate Matter $\left(\mathrm{PM}_{10}\right)$}

The data of aerosol load was collected to record seasonal variation in the status of air-borne $\mathrm{PM}_{10}$ and to correlate them with anthropogenic activity. The knowledge of aeorsol load is important as it affects the climate change in local area. A continuous monitoring is required to know the seasonal effect in developing cities due to local factors.

The monthly average of 24 hourly average value of $\mathrm{PM}_{10}$ are shown in Figure 2 which ranges from 66 to $312 \mu \mathrm{g} / \mathrm{m}^{3}$ in residential area, from 120 to $570 \mu \mathrm{g} / \mathrm{m}^{3}$ at highway and from 81 to $262 \mu \mathrm{g} / \mathrm{m}^{3}$ at university campus. The highest values were observed in February followed by May. The highway area was observed to be more polluted than residential area, which in turn was more polluted than university campus.

The high $\mathrm{PM}_{10}$ concentration at highway is as a result of various commercial activity and high traffic density, as this is National Highway-1 connecting Delhi to North India. This sampling site is actually a crossroad between Sonepat and $\mathrm{NH}-1$, where sometimes a congestion of vehicle occurs due to traffic bottlenecks and absence of signals. In addition to this aerosol particles are also emitted into atmosphere due to abrasion process of automobiles components such as brake or tire wear [20]. 


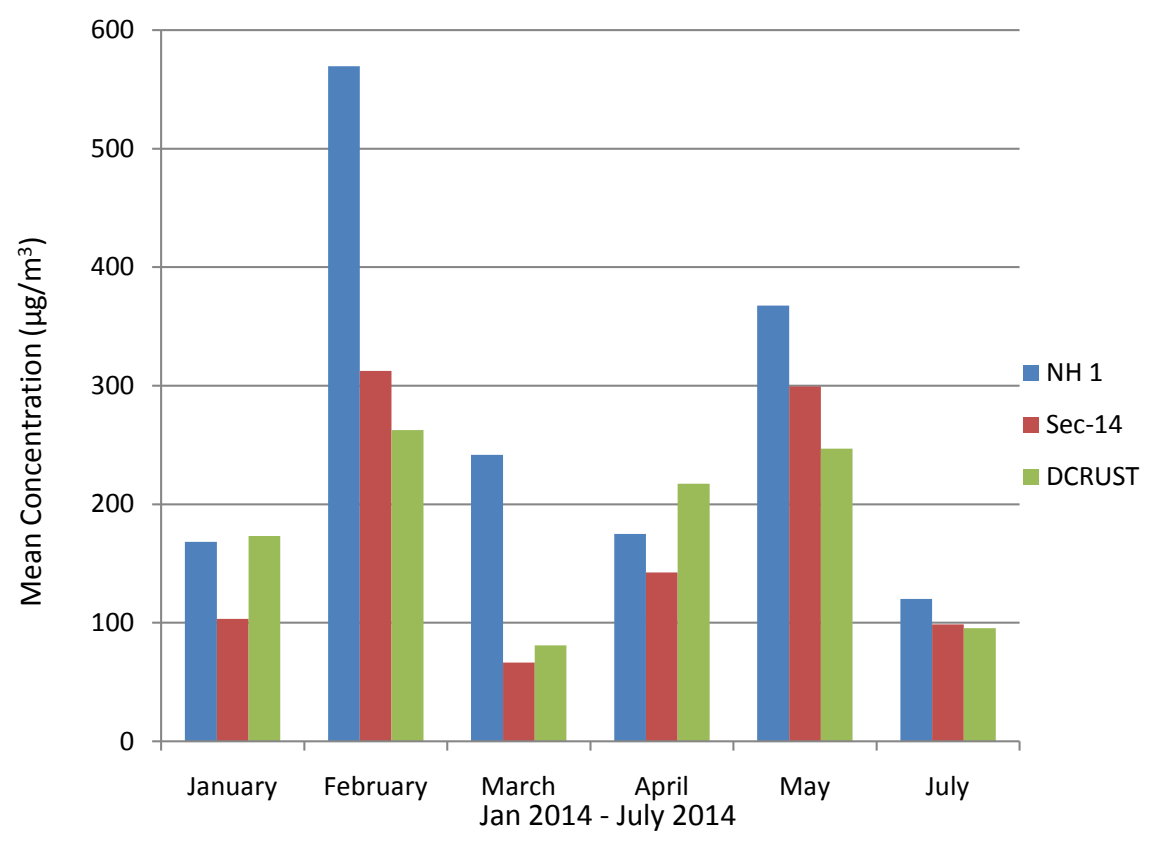

Figure 2. $\mathrm{PM}_{10}$ concentration in Sonepat city in $\mu \mathrm{g} / \mathrm{m}^{3}$.

The second sampling station was a university campus with adequate vegetation and better maintenance but it is not far away from NH-1. The comparatively less concentration of particulate matter in the university campus may be attributed to the good vegetation in campus.

The concentration of $\mathrm{PM}_{10}$ in Sonepat city indicates that the level of particulate matter has increased significantly. This is due to urbanisation, increase traffic density, construction activity, biomass burning and poor condition of roads. The concentration of $\mathrm{PM}_{10}$ in Sonepat city was found to be exceeding the permissible limit. An interesting relationship has been observed, between population density and suspended particulate matter which shows that particulate matter concentration hardly depends on the local meteorology and climate of the place; rather it depends upon the local polluting sources [21]. Due to urbanisation the air quality of cities is deteriorating at a very high rate. Kannan and Kapoor [22] shows that particulates encountered in urban areas in India are appreciably higher especially during winter and summer months.

Road dust resuspension is also a major contributor to $\mathrm{PM}_{10}$ during all seasons. There is found to be significant variation in aerosol load with season. The dry deposition of aerosols is a effect of both natural and anthropogenic sources. The entire data of various months was grouped to know the seasonal variation. The season from January to March is spring and is associated with low wind speed and less rain resulting in increase of air pollution. High concentration of particulate matter in February may be due to calm wind conditions, moderate temperature and scanty rainfall. Whereas high concentration of particulate matter in summer from April to June, is associated with strong winds and low humidity. This may also be attributed to the harvesting period as the area is surrounded by fields and burning of paddy takes place in April-May despite ban from Govt. of 
Haryana.

In contrast July is monsoon season with low wind speed and medium to high precipitation which reduces air pollution due to scavenging effects of rain and is reflected in $\mathrm{PM}_{10}$ concentration in July. Rain in the area in July makes atmosphere clean from dust particles. This suggests that monsoon has a cleansing effect on atmosphere. Particulate matters are potentially dangerous for human health. These small particles can penetrate deep in to the lungs and causes various health problems like asthma, bronchitis etc.

\subsection{Seasonal Variation of Heavy Metals}

The heavy metals are associated with respirable dust particles in urban air and penetrates deep into lungs and cannot be flushed out easily. The presence of heavy metal in particulate matter can be attributed to anthropogenic as well as geological origin in the city. The heavy metal concentration was determined only at one station i.e. $\mathrm{NH}-1$ which was having highest $\mathrm{PM}_{10}$ load. The concentration of heavy metals in the atmosphere ranged as $\mathrm{Zn}\left(\mathrm{ND}-25.6 \mu \mathrm{g} / \mathrm{m}^{3}\right)$, Copper (1.4 $22.85 \mu \mathrm{g} / \mathrm{m}^{3}$ ), and Chromium (5.21 - $27.42 \mu \mathrm{g} / \mathrm{m}^{3}$ ). The order of average concentration of heavy metals was in the order $\mathrm{Cr}>\mathrm{Cu}>\mathrm{Zn}$. $\mathrm{Pb}$ concentration was found to be below detection limit in all months and this could be attributed to use of unleaded petrol in vehicles, which used to be a major contributor of lead in urban areas [23]. The high concentration of $\mathrm{Zn}$ and $\mathrm{Cr}$ could be correlated with the emission from various industries and abrasion from automobiles [24]. Bhaskar et al., [25] studied $\mathrm{Fe}, \mathrm{Zn}, \mathrm{Cd}$ and $\mathrm{Cr}$ in atmospheric aerosols in Madurai and found to be varying from 0.012 to $2.260 \mu \mathrm{g} / \mathrm{m}^{3}, 0.08$ to $16.51 \mu \mathrm{g} / \mathrm{m}^{3}$, 0.001 to $0.029 \mu \mathrm{g} / \mathrm{m}^{3}$ and 0.005 to $0.48 \mu \mathrm{g} / \mathrm{m}^{3}$ respectively. Total concentration of all three metals in $\mathrm{PM}_{10}$ is given in Table 1 in various months. The high concentration of heavy metals is a reflection of increased vehicular emission and industrial activity in the area as the National highway region is having high vehicular load connecting North India to National Capital. On looking into monthly variation it can be analysed that relatively high concentration of heavy metals is observed in winter than spring season as depicted in Figure 3. Kaveri and Paul [26], has also observed low concentration of $\mathrm{PM}_{10}$, heavy metals and anions in summer season than winter in Steel city, Rourkela, India.

In cities the major components of airborne particulate matter are inorganic ions, metallic constituents and organic compounds [27]. The cations like $\mathrm{Na}^{+}$,

Table 1. Heavy metals concentration (in ppm) from Jan 2014 to April 2014 in aerosols at $\mathrm{NH}-1$ in Sonepat.

\begin{tabular}{cccc}
\hline Month & Zinc $(\mathrm{Zn})$ & Copper $(\mathrm{Cu})$ & Chromium $(\mathrm{Cr})$ \\
\hline January & $13.8 \pm 2.35$ & $16.5 \pm 3.11$ & $24.1 \pm 3.89$ \\
February & $19.7 \pm 1.51$ & $16.54 \pm 2.17$ & $18.74 \pm 4.21$ \\
March & Below detection limit & $2.1 \pm 1.87$ & $7.24 \pm 1.69$ \\
April & $5.46 \pm 1.47$ & $11.1 \pm 5.60$ & $19.7 \pm 3.32$ \\
\hline
\end{tabular}


$\mathrm{NH}_{4}^{+}, \mathrm{K}^{+}, \mathrm{Ca}^{2+}$, and $\mathrm{Mg}^{2+}$, anions like $\mathrm{F}^{-}, \mathrm{Cl}^{-}, \mathrm{NO}_{3}^{-}, \mathrm{PO}_{4}^{3-}, \mathrm{SO}_{4}^{2}$ and other secondary organic aerosols are found to be most common components of secondary particles in the atmosphere. These particles are formed in the atmosphere due to chemical transformation of gaseous pollutants like $\mathrm{SO}_{2}$ and $\mathrm{NO}_{\mathrm{x}}$ [28]. Thus major cations were also studied during the present study. As clearly seen from Figure 4 the concentration of $\mathrm{Na}^{+}, \mathrm{NH}_{4}^{+}, \mathrm{K}^{+}, \mathrm{Ca}^{2+}, \mathrm{Mg}^{2+}$ at sector 14 is $52.11 \mathrm{ppm}, 6.75 \mathrm{ppm}, 13.98 \mathrm{ppm}, 105.84 \mathrm{ppm}$ and $72.57 \mathrm{ppm}$ respectively. Where as the concentration of $\mathrm{Na}^{+}, \mathrm{NH}_{4}^{+}, \mathrm{K}^{+}, \mathrm{Ca}^{2+}, \mathrm{Mg}^{2+}$ at DCRUST was $207.58 \mathrm{ppm}, 0.550 \mathrm{ppm}, 50.57 \mathrm{ppm}, 90.65 \mathrm{ppm}$ and $85.02 \mathrm{ppm}$ respectively.

According to Yusuf and Rashid [29] a high concentration of $\mathrm{Ca}^{2+}$ originates from carbonates generated from alkaline sources such as soil dust and earth crust while the $\mathrm{Mg}^{2+}$ ion can be the result of sea spray particles which have been washed down by precipitation. $\mathrm{F}^{-}, \mathrm{Cl}^{-}, \mathrm{SO}_{4}^{3-}$, and $\mathrm{NH}^{4+}$ are also released into the environment via coal combustion and process waste from various industrial processes and anthropological activities associated with the sampling site. The concentration of $\mathrm{K}^{+}$is found to be 13.89 and $50.54 \mathrm{ppm}$ at Sector -14 and DCRUST respectively. Normally soil is considered to be main source of $\mathrm{K}^{+}$. The fine particle of $\mathrm{K}^{+}$may be released into the atmosphere by burning of plant material [30]. The presence of $\mathrm{NH}^{4+}$ may be attributed to the reaction of $\mathrm{NH}_{3}$ vapours with acidic gases may react or condense on an acidic particle surface of

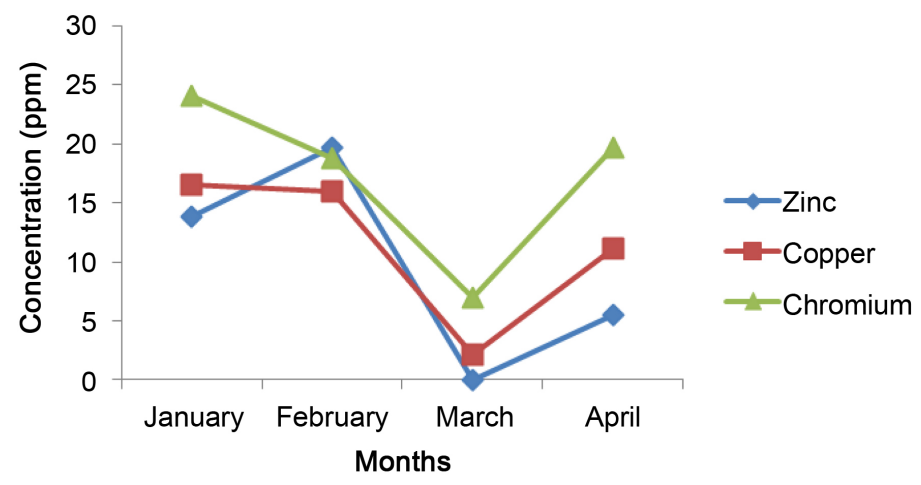

Figure 3. Monthly variation of heavy metal concentration (Jan 2014April 2014) in Sonepat.

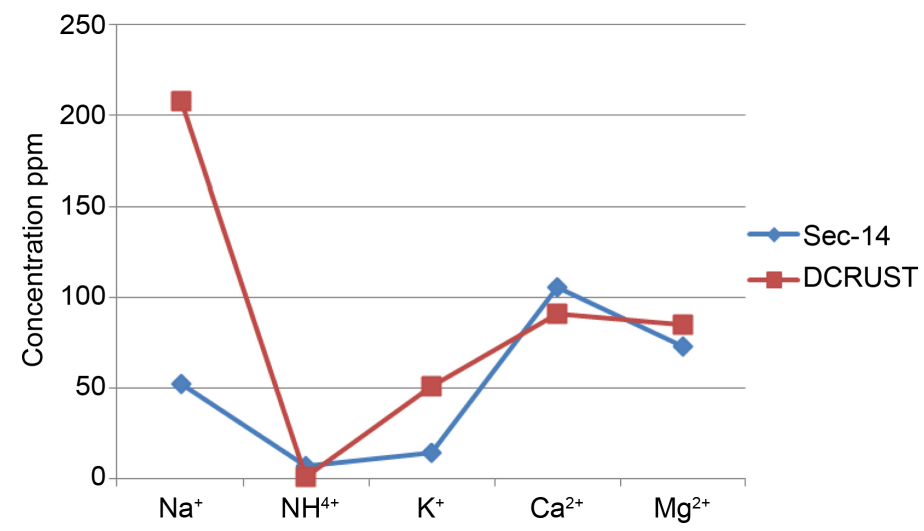

Figure 4. Concentration of cations at Sector 14 and DCRUST Sonepat. 
anthropogenic origin. $\mathrm{K}^{+}$is a useful tracer for pyrogenic aerosols in plants; it is an important component that originates from burning of vegetative material [31]. Sodium comes in to environment because of weathering of rocks and it occurs naturally in environment.

\section{Conclusion}

In the present study, the chemical characterisation of $\mathrm{PM}_{10}$ was done on samples collected from developing city Sonepat. As this was the first study done in the region concerning anions, heavy metal and $\mathrm{PM}_{10}$ load, we could not compare it with previous studies. The $\mathrm{PM}_{10}$ concentration in the region shows that it was season specific and wind direction and humidity plays a crucial role. The $\mathrm{PM}_{10}$ concentration was higher than permissible limit of Central Pollution Control Board, India. The three metals $\mathrm{Zn}, \mathrm{Cu}$ and $\mathrm{Cr}$ were also quantified from $\mathrm{PM}_{10}$ concentration. The concentrations of heavy metals were substantial in traffic area and so might be correlated with traffic density. The gaseous pollutants serves as precursors of ionic particle so were studied along with. There is need of study of source apportionment along with aerosol study to avoid health problems due to exposure of heavy metals.

\section{Acknowledgements}

The first author is a thankful to University Grant Commission, New Delhi for Start Up Grant provided.

\section{References}

[1] Charlson, R.J., Schwartz, S.E., Hales, J.M., Cess, R.D., Coakley, J.A., Hansen, J.E. and Holmann, D.J. (1992) Climate Forcing by Anthropogenic Aerosols. Science, 255, 424-430. https://doi.org/10.1126/science.255.5043.423

[2] Toon, B.D. (2000) How Pollution Suppress Rain. Science, 287, 1763-1764. https://doi.org/10.1126/science.287.5459.1763

[3] Srivastava, K.P. and Singh, V.K. (2012) Impact of Air Pollution on pH of Soil of Saran, Bihar, India. Research Journal Recent Science, 1, 9-13.

[4] Chouhan, A., Iqbal, S., Maheshwari, R.S. and Bafna, A. (2012) Study of Air Pollution Tolerance Index of Plants Growing in Pithampur Industrial Area Sector 1, 2 and 3. Research Journal Recent Science, I (ISC-2011), 172-177.

[5] Lee, C.S.L., Li, X.D., Zhang, G., Li, J., Ding, A.J. and Wang, T. (2007) Heavy Metals and $\mathrm{Pb}$ Isotopic Composition of Aerosols in Urban and Suburban Areas of Hong Kong and Guangzhou, South China-Evidence of the Long-Range Transport of Air Contaminants. Atmospheric Environment, 41, 432-447.

[6] Ali-Mohamed, A.Y. (1991) Estimation of Inorganic Particulate Matter in the Atmosphere of Isa Town, Bahrain, by Dry Deposition. Atmospheric Environment Part $B, 25,397-405$.

[7] Cancio, J.L., Castellano, A.V., Hernández, M.C., Bethencourt, R.G. and Ortega, E.M. (2008) Metallic Species in Atmospheric Particulate Matter in Las Palmas de Gran Canaria. Journal of Hazardous Materials, 160, 521-528.

[8] Leili, M., Naddafi, K., Nabizadeh, R. and Yunesian, M. (2008) The Study of TSP and $\mathrm{PM}_{10}$ Concentration and Their Heavy Metal Content in Central Area of Tehran, 
Iran. Air Quality, Atmosphere \& Health, 1, 159-166.

https://doi.org/10.1007/s11869-008-0021-z

[9] Park, K., Heo, Y. and Putra, H.E. (2008) Ultrafine Metal Concentration in Atmospheric Aerosols in Urban Gwangju, Korea. Aerosol and Air Quality Research, 8. 411-422.

[10] Xu, Y.H., Wu, J.H., Feng, Y.C., Dai, L., Bi, X.H., Li, X., Zhu, T., Tang, S.B. and Chen, M.F. (2010) Source Characterization and Apportionment of $\mathrm{PM}_{10}$ in Panzhihua, China. Aerosol and Air Quality Research, 10, 367-377. https://doi.org/10.4209/aaqr.2010.01.0002

[11] Cheung, K., Daher, N., Kam, W., Shafer, M.M., Ning, Z., Schauer, J.J. and Sioutas, C. (2011) Spatial and Temporal Variation of Chemical Composition and Mass Closure of Ambient Coarse Particulate Matter (PM 10 - 2.5) in the Los Angeles Area. Atmospheric Environment, 45, 2651-2662. https://doi.org/10.1016/j.atmosenv.2011.02.066

[12] Kothai, P., Saradhi, I.V., Prathibha, P., Hopke, P.K., Pandit, G.G. and Puranik, V.D. (2008) Source Apportionment of Coarse and Fine Particulate Matter at Navi Mumbai, India. Aerosol and Air Quality Research, 8, 423-436.

[13] C.P.C.B. (2003) Parivesh: Polycyclic Aromatic Hydrocarbons (PAHs) in Air and Their Effects on Human Health. Central Pollution Control Board, Ministry of Environment and Forest, Delhi, 20. http://www.cpcb.delhi.nic.in/ph/ch81103.html

[14] Gokhale, S.B. and Patil, R.S. (2004) Size Distribution of Aerosols (PM10) and Lead $(\mathrm{Pb})$ near Traffic Intersections in Mumbai (India). Environmental Monitoring and Assessment, 95, 311-324. https://doi.org/10.1023/B:EMAS.0000029911.81865.b6

[15] Ravindra, K., Wauters, E., Taygi, S.K., Mor, S. and Grieken, R.V. (2005) Assessment of Air Quality after the Implementation of CNG as Fuel in Public Transport in Delhi, India. Environmental Monitoring and Assessment, 115, 405-417. https://doi.org/10.1007/s10661-006-7051-5

[16] Akoto, O., Bruce, T.N. and Darko, G. (2008) Heavy Metals Pollution Profiles in Streams Serving the Owabi Reservoir. African Journal of Environmental Science and Technology, 2, 354-359.

[17] Berico, M., Luciani, A. and Formignani, M. (1997) Atmospheric Aerosol in Urban Area-Measurements of TSP and PM10 Standards and Pulmonary Deposition Assessments. Atmospheric Environment, 31, 3659-3665. https://doi.org/10.1016/S1352-2310(97)00204-5

[18] Künzli, N., Kaiser, R., Medina, S., Studnicka, M., Chanel, O., Filliger, P., Herry, M., Horak Jr, F., Puybonnieux-Texier, V., Quénel, P., Schneider, J., Seethaler, R., Vergnaud, J.-C. and Sommer, H. (2000) Public-Health Impact of Outdoor and Traffic-Related Air Pollution: A European Assessment. Lancet, 356, 795-801.

https://doi.org/10.1016/S0140-6736(00)02653-2

[19] Pruseth, K.L., Yadav, S., Mehta, P., Pandey, D. and Tripathi, J.K. (2005) Problems in Microwave Digestion of High-Si and High-Al Rocks. Current Science-Bangalore, 89, 1668.

[20] Viana, M., Querol, X. and Alastuey, A. (2006) Chemical Charecterisation of Pm Episodes in North-Eastern Spain. Chemosphere, 62, 947-956. https://doi.org/10.1016/j.chemosphere.2005.05.048

[21] Prasad, R. (2004) Urban Air Quality-Some Interesting Observations. Our Earth, 1, 8-11.

[22] Kannan, G.K. and Kapoor, J.C. (2004) Relationship of Sulphur Dioxide and Its Particulate Converts in the Urban Ambient Air. Indian Journal of Air Pollution Con- 
trol, 4, 1-8.

[23] Jeba Rajasekhar, R.V., Tennyson, D. and Muthusubranian, P. (2005) Vehicular Emission Loads of Gaseous Pollutants in Madurai City. Asian Journal of Microbiology, Biotechnology and Environmental Science, 7, 427-430.

[24] Vertika, S. and Upreti, D.K. (2007) Heavy Metals Accumulation in Phacophyscia hispidula en Route to Badrinath, Uttaranchal, India. Environmental Monitoring and Assessment, 131, 365-369. https://doi.org/10.1007/s10661-006-9481-5

[25] Bhaskar, B.V., Jeba Rajasekhar, R.V., Muthusubranian, P. and Kesarkar, A.P. (2010) Ionic and Heavy Metal Composition of Respirable Particulate in Madurai, India. Environmental Monitoring and Assessment, 164, 323-336. https://doi.org/10.1007/s10661-009-0895-8

[26] Kaveri, N.C. and Paul, K.K. (2013) Chemical Characterisation of Ambient PM10 Aerosol in a Steel City, Rourkela, India. Research Journal of Recent Sciences, 2, 32-38.

[27] Laschober, C., Limbeck, A., Rendel, J. and Puxbaum, H. (2004) Particulate Emission from On-Road Vehicles in the Kaisermuhlen-Tunnel (Vienna, Austria). Atmospheric Environment, 38, 2187-2195. https://doi.org/10.1016/j.atmosenv.2004.01.017

[28] Lin, J.J. (2002) Characterisation of Water Soluble Ion Species in Urban Ambient Particles. Environment International, 28, 2187-2195. https://doi.org/10.1016/S0160-4120(02)00004-1

[29] Yusuf, S.I. and Rashid, M. (1995) Analysis of Wet Acidic Deposition in Petaling Jaya. SOMCE95 Conference, Kuala Terengganu, 18-19 June 1995, A17, 1-5.

[30] Mouli, P.C., Mohan, S.V. and Reddy, S.J. (2006) Chemical Composition of Atmospheric Aerosol (Pm10) at a Semi-Arid Urban Site: Influence of Terrestrial Sources, Environmental Monitoring and Assessment, 117, 291-305. https://doi.org/10.1007/s10661-006-0988-6

[31] Hsu, Y.-C., Lai, M.-H., Wang, W.-C., Chiang, H.-L. and Shieh, Z.-X. (2008) Characteristics of Water-Soluble Ionic Species in Fine (PM2.5) and Coarse Particulate Matter (PM 10 - 2.5) in Kaohsiung, Southern Taiwan. Journal of the Air \& Waste Management Association, 58, 1579-1589.

https://doi.org/10.3155/1047-3289.58.12.1579

\section{Submit or recommend next manuscript to SCIRP and we will provide best service for you:}

Accepting pre-submission inquiries through Email, Facebook, LinkedIn, Twitter, etc. A wide selection of journals (inclusive of 9 subjects, more than 200 journals)

Providing 24-hour high-quality service

User-friendly online submission system

Fair and swift peer-review system

Efficient typesetting and proofreading procedure

Display of the result of downloads and visits, as well as the number of cited articles

Maximum dissemination of your research work

Submit your manuscript at: http://papersubmission.scirp.org/

Or contact ojap@scirp.org 